\title{
The Stability and Growth Pact, and Balanced Budget Fiscal Stimulus: Evidence from Germany and Italy
}

\author{
Konstantinos Karagounis, Dimitrios Syrrakos, and John Simister \\ Manchester Metropolitan University Business School, UK
}

\begin{abstract}
This paper assesses the limitations that the Stability and Growth Pact has imposed on Italy's economic recovery and its debt reduction. By evaluating Germany's fiscal policy since 1997, the paper offers recommendations for the Italian authorities. Measures put forward by European Union institutions are hampering Italy's economic recovery and evidence indicates that fiscal consolidation is ineffective in reducing the debt-to-GDP ratio. A balanced-budget fiscal injection seems the only way for Italy to escape from economic slump without further violations of the SGP. The paper concludes that the Pact needs to be reformed, or replaced by a central fiscal authority. (JEL E62, E63)
\end{abstract}

\section{Introduction}

The collapse of Lehman Brothers in 2008 led to a global financial and economic crisis. The lack of available capital together with the imbalances in the European Monetary Union (EMU) member countries' current account component of their balance of payments led to the EMU debt crisis in 2009-10. Whereas the German economy has emerged from the EMU debt crisis quite strong, the Italian economy has not experienced a similar pattern of recovery (Lane 2012, p. 50). Hence, for this paper, Germany is used as a model for considering Italy's policy options. The paper evaluates the economic performance of the German and Italian economies in the context of the Stability and Growth Pact (SGP) by focusing on their ability to meet the SGP criteria. It argues that in order to reduce its debt-to-GDP ratio, Italy must pursue policies aiming to stimulate growth before undertaking long-term structural reforms. A balanced-budget fiscal expansion may be the only policy for a country to achieve growth within the SGP rules.

The rest of the paper is presented as follows. In Section II, the literature review explains the rationale of the SGP and provides a background to the German and Italian economies. Sections III and IV assess the two countries' performance in the EMU and during the Euro-zone crisis; 
Section V compares Italy with Germany; Section VI assesses the policy options and proposes a course of action for Italian and EMU policymakers; finally, the conclusion summarizes the paper's findings.

\section{Literature Review}

The SGP is a European Union (EU) rule-based framework that attempts to ensure fiscal sustainability through an early warning mechanism and with potential sanctions for Euro-zone countries only (De Grauwe 2012; Eijffinger \& De Haan 2008). It stipulates that government deficits should not exceed three per cent of Gross Domestic Product (GDP) and total government debt should not exceed 60 per cent of GDP. If national debt exceeds 50 per cent of GDP, then governments should necessarily register deficits below three per cent of GDP. The growth in government expenditure must not outpace growth in gross national product and, where member states do not comply with the Excessive Deficit Procedure (EDP), multilateral sanctions up to 0.5 per cent of GDP may be imposed (European Union 1997, articles 121, 126, 136 and Protocol 12). Since the global financial crisis and the subsequent EMU debt crisis, only the debt and deficit thresholds remain relevant. The SGP was reformed in 2005 to take into account the effects of cyclical fluctuations on budget positions. In 2011 the SGP was reformed again to strengthen its surveillance and enforcement capabilities as it did not provide enough discipline to the member states (Lane 2012, p. 62). However, neither the debt nor the deficit thresholds were changed, and still remain a sclerotic aspect of EMU.

In the run-up to EMU, many potential risks of monetary union surfaced, such as member states adopting a loose fiscal policy (Eijffinger \& De Haan 2008). With access to a much larger capital market and lower interest rates governments could potentially engage in reckless borrowing and spending. Such policies could cause two negative externalities. First, moral hazard, if creditor states are forced to tighten their fiscal policies in response to overspending by debtor states. Second, spill-over effects, if one state faces a debt crisis (Eijffinger \& De Haan 2008; De Grauwe 2012). Furthermore, unsustainable sovereign debt risked causing price instability, which could hinder the functioning of the European Central Bank (ECB) whose mandate is to maintain EMU-wide inflation at a rate below but close to two per cent (Collignon 2004). A fiscal and a banking union would complete EMU; but a central fiscal authority remains politically elusive, due to state sovereignty and subsidiarity. The SGP was established to prevent these externalities, but was designed to leave the member states' fiscal autonomy intact: a balance very difficult to strike.

Despite implementing different economic policies, the German and Italian economies shared similar patterns following the creation of the EMU, on 1 January 1999. The challenges faced by each country during the EMU debt crisis were different but Germany's resilience reinforced its role as a model European economy. Thus, despite apparent differences between the Italian and German economies, European institutions pointed to the German model when proposing solutions to Italy's debt crisis. This paper provides a comparative analysis of the two economies to assess the effectiveness of such proposals. The comparison is made possible by a number of 
similarities between the two economies. For example, they rank as first and third largest economies in the EMU in terms of GDP (World Bank 2013). They both maintain large global trading sectors, with a substantial share of intra-EU trade and high volumes of bilateral trade. Each country has great regional disparities: in Germany the former Soviet, Eastern part of the country still lags considerably in relation to the Western regions of the country whereas Italy is characterised by an underperforming South. Both experienced the lowest average growth rates of all Euro-zone countries in the first half of the 2000s (EC 2006) and both were in violation of the SGP from 2001 to 2005 . However, Germany performed much better than Italy since the onset of the global financial crisis. Germany's debt rarely exceeded 60 per cent of GDP before 2008 whereas Italy's debt-to-GDP ratio exceeded 100 per cent since the early 1990s, and it has never met the 60 per cent debt-to-GDP criterion (Lane 2012, p. 51).

Throughout the first half of the 2000s, both countries' competitiveness declined significantly. For Germany, this was partly due to the lingering costs of unification, but also because it joined the Euro at an overvalued exchange rate (EC 2006). For Italy, this was largely because it could no longer rely on devaluation to regain competitiveness losses. German authorities engaged in a series of labour market and other structural reforms - which improved competitiveness, and arguably allowed its labour force to remain relatively robust during the economic downturn of 2007-09. On the other hand, no such policies were put in place or at least rendered effective in Italy. Consequently, Germany is now one of the world's largest exporters of vehicles, machinery and chemicals (OECD 2011), with a relatively price-inelastic product specialisation. Conversely, in the past decade, Italian exports declined as its product specialisation came into direct competition with Asian economies (EC 2012b).

Major obstacles to growth in both countries during the early 2000s were stagnant domestic demand, structural rigidities and low productivity growth - in the case of Germany, stagnation was accompanied by a major rise in unemployment (Figure 4). The extended period of low growth led to structural unemployment in Germany and declining growth for both Germany and Italy. Since the 2008 global financial crisis, both economies rebounded, although Italy's recovery has been much more modest than Germany's.

\section{Germany and the SGP}

Germany is often regarded as a fiscally prudent economy, but was amongst the first states to be subjected to the EDP after violating the three per cent deficit-to-GDP threshold: Germany's deficit exceeded three per cent of GDP every year between 2001 and 2006, and its debt ratio remained in excess of the SGP threshold since 2002 (Figures 1 and 2). According to the European Commission (EC) (2006), these consecutive deficits were largely due to overprojections of GDP, which remained at just over one per cent during that period. Sluggish growth led to lower tax revenues making it difficult to reduce deficits. However, as evident in Figure 3, the expenditure ratio increased between 2000 and 2003 whereas the revenue ratio was reduced or virtually unchanged even after Germany's economic recovery. Germany therefore failed to 
comply with the EDP in 2005, but was not punished with sanctions. Whilst violating the SGP, Germany had the fiscal flexibility to boost its GDP growth.

\section{Figure 1}

\section{Net lending (+)/Net borrowing (-) (\% of GDP)}

Source: Data from the European Commission, Eurostat (2014)

Underscoring Germany's low growth potential in the first half of the 2000s were its sluggish domestic consumption and its high unemployment; unemployment reached one of its highest post-war levels at 11.5 per cent (Figure 4). However, following a series of structural reforms between 2003 and 2005, the unemployment rate declined. These reforms, popularly known as the 'Hartz reforms', attempted to increase labour flexibility and improve productivity and competitiveness (Burda 2007). After 2005, GDP began to increase and the country's public finances recovered. The budget deficit of 2004 became a moderate surplus by 2007, and the debtto-GDP ratio declined. However, the global financial crisis resulted in deterioration of German public finances and the excessive deficits of 2009 and 2010.

\section{Figure 2}

\section{Government gross consolidated debt (\% of GDP)}

Source: Data from the European Commission, Eurostat (2014)

Since 2008, GDP fell sharply for Germany and its trading partners. Due to Germany's reliance on trade and its specialisation in investment goods, the downturn in global investment caused one of the sharpest declines in GDP of the world's industrialised economies (EC 2009). However, well-functioning automatic stabilisers and discretionary fiscal expansionary policies helped boost economic growth. In addition, after three years of budget surpluses prior to 2009, Germany's public finances did not suffer as much as some of its EMU partners. During the crisis the German government adopted measures including capital injections and guarantees to stabilise the faltering banking sector (EC 2009; OECD 2011). Although this added to deficits in 2009 and 2010, the combined effect of these measures had a positive effect on GDP and resulted in a strong recovery from the crisis

\section{Figure 3}

\section{Expenditure and revenue (\% of GDP) - Germany}

Source: Data from the European Commission, Eurostat (2014)

After successive deficits in the first half of the 2000s, Germany's debt ratio passed the SGP threshold and reached 67 per cent of GDP in 2006 Q4. However, due to changes in German exports, domestic demand began to improve and its GDP growth started outperforming the Eurozone average (EC 2009). As a result, debt as a percentage of GDP declined but then increased 
sharply during the global financial crisis. Largely due to negative cyclical conditions (EC 2011), German debt-to-GDP increased by 10.6 per cent between 2008 Q3 and 2009 Q4. On the other hand, the sharp increase in the debt ratio between the third and fourth quarters of 2010 is almost entirely due to the government's purchase of 'bad assets' from the banking sector (EC 2011). Germany's budget balance and GDP growth since 2007 (Figure 5) show a striking resilience to the global financial crisis and the subsequent Euro-zone crisis. German GDP fell more than most other Euro-zone economies in 2009, but growth recovered almost immediately and has since outperformed the Euro-zone average. The 2010 deficit at 4.1 per cent of GDP (Figure 1) was reduced to a deficit of 0.8 per cent of GDP a year later, whilst the debt ratio has stabilised.

\section{Figure 4}

\section{Harmonised unemployment rate}

Source: Data from the European Commission, Eurostat (2014)

\section{Figure 5}

\section{GDP growth, Index 2005 Q1=100}

Source: Data from the European Commission, Eurostat (2014)

The largest contributing factor to Germany's economic recovery is its export growth. Figure 6 shows that GDP growth has a very strong positive association with exports as a percentage of GDP (there may be a bidirectional causality between GDP growth and exports; determining such a relation is beyond the scope of this paper). Although its increased reliance on trade to boost GDP growth predisposed Germany to the downturn in global demand, it is also what characterises its current stability and resilience to the Euro-zone crisis. Figure 8 helps clarify how the composition of Germany's exports boosted its recovery. Both intra-EU and extra-EU trade in goods followed upward trends until 2007. Between 2002 and 2007 there was little improvement in the balance of Germany's extra-EU trade but during the same period, the balance of intra-EU trade became the main component of Germany's total trade surplus. At the trough of European economic activity in 2009, German intra-EU trade balance deteriorated to its pre-2002 level. Yet despite the ensuing Euro-zone crisis, the German economy was able to recover through an improved external trade balance (EC 2010). With external trade accounting for approximately 74 per cent of Germany's trade surplus, there has been a clear shift. When intra-EU trade waned, Germany was able to access Asian markets to maintain GDP growth; this diversity explains, in part, Germany's ability to remain resilient in the ensuing crisis.

\section{Figure 6}

\section{GDP and exports (\% of GDP) - Germany}

Source: Data from the European Commission, Eurostat (2014) 
The primary reason for sluggish private consumption in Germany between 1997 and 2006 was the fact that real disposable incomes were virtually unchanged. This wage moderation led to major improvements in cost competitiveness (Burda 2007). German labour markets arguably became much more flexible as a result of the 'Hartz' reforms, which allowed the economy to absorb shocks without major losses in employment (Burda 2007). Germany's economic policies since 1997 demonstrate considerable sacrifices whilst other EMU members enjoyed protracted periods of growth and prosperity. Although this reflects foresight by German policymakers, it must be emphasised that these reforms were made possible by deviating from the SGP criteria. This leeway allowed Germany to engage in fiscal stimulus and enact a series of reforms which helped develop a robust economy and enabled a strong recovery from the global financial crisis.

\section{Italy and the SGP}

Italy suffered chronic and extremely high debt-to-GDP ratios, currently at 130 per cent of GDP and likely to continue rising. Efforts to reduce the debt ratio between 2000 Q2 and 2004 Q4 (Figure 2) did not have a lasting effect, and in recent years have seen sharp increases. The Italian government has maintained a primary surplus ever since joining the EMU with the exception of 2009 (Figure 7); Italy has been one of the best performing Euro-zone economies in terms of its primary balance. Even though the primary balance deteriorated considerably between 2000 and 2005 (according to EC 2006), this was the result of over-projections of GDP rather than loose fiscal policy. Despite a prudent fiscal stance, Italy's debt ratio increased by 15 per cent since the establishment of the SGP.

\section{Figure 7}

\section{Debt components - Italy}

Source: Data from the European Commission, Eurostat (2014)

Figure 1 demonstrates that between 2001 and 2006, Italy's budget deficit consistently exceeds three per cent of GDP. Under the EDP, Italy reduced its deficit to below three per cent in 2007. Following the global financial crisis, it rose in 2009 to its highest level since 1996 at 5.4 per cent of GDP. The cause for these deficits, and hence the increase in the debt-to-GDP ratio, is the government's vast interest expenditure on past debt and not fiscal recklessness (Figure 7). The deficits are caused by interest repayments on debt, which lead to further debt accumulation. Excessive debt is both the cause and the symptom of Italy's persistent deficits. Figure 7 illustrates that in each year, the interest payments exceed the primary surpluses (the difference between the two comprises the total budget deficit, which is added to the debt burden). Moreover, with average GDP growth of 0.7 per cent since joining EMU (Figure 5), it has been near impossible for Italy to escape this vicious circle.

Currently, any deficit spending will put Italy in violation of the SGP and may expose it to sanctions; making it even harder to meet the SGP criteria. In 2009, Italy's annual GDP fell by 5.5 
per cent. With already poor public finances, Italy's ability to engage in fiscal stimulus was and remains severely restricted by the SGP (Buti \& Carnot 2013). Declining nominal GDP and subsequent deficit spending between 2008 and 2009 caused an increase in the Italian debt ratio of almost 14 per cent (EC 2012c), and the primary balance went into deficit for the first time since 1990. However, tax reforms led to increased revenue and pushed the primary balance into surplus, despite a declining GDP (EC 2012b), indicating a notable effort by the Italian authorities. Nevertheless, the debt ratio continues to rise even as the primary balance improves. In its current pace, and based on the current EMU GDP forecasts, fiscal consolidation will most likely remain ineffective in reducing the debt ratio.

\section{Comparative Analysis}

Germany's budget balance and GDP growth since 2007 (Figure 5) shows a striking resilience to the global financial crisis and the subsequent Euro-zone crisis. German GDP fell more than most other Euro-zone economies in 2009, but growth recovered almost immediately and has since outperformed the Euro-zone average. The 2010 deficit at 4.1 per cent of GDP (Figure 1) was reduced to a deficit of 0.8 per cent of GDP a year later, whilst the debt ratio has stabilised. The largest contributing factor to this recovery is its export growth. Figure 6 shows that GDP growth has a very strong positive association with exports as a percentage of GDP (there may be a bidirectional causality between GDP growth and exports; determining such a relation is beyond the scope of this paper). Although its increased reliance on trade to boost GDP growth predisposed Germany to the downturn in global demand, it is also what characterises its current stability and resilience to the Euro-zone crisis.

\section{Figure 8}

\section{Trade balance of goods}

Source: Data from the European Commission, AMECO (2014)

Figure 8 helps clarify how the composition of Germany's exports boosted its recovery. Both intra-EU and extra-EU trade in goods followed upward trends until 2007. Between 2002 and 2007 there was little improvement in the balance of Germany's extra-EU trade but during the same period, the balance of intra-EU trade became the main component of Germany's total trade surplus. At the trough of European economic activity in 2009, German intra-EU trade balance deteriorated to its pre-2002 level. Yet despite the ensuing Euro-zone crisis, the German economy was able to recover through an improved external trade balance (EC 2010). With external trade accounting for approximately 74 per cent of Germany's trade surplus, there has been a clear shift. When intra-EU trade waned, Germany was able to access Asian markets to maintain GDP growth; this diversity explains Germany's ability to remain resilient in the ensuing crisis. Thus, one of the biggest differences between the two countries is the geographical destination of their exports. Germany has covered its loss of intra-EU trade by accessing Asian markets. Italy's exports, on the other hand, suffered from a decade of exposure to the German market (its largest 
trading partner), which experienced almost a decade of stagnant demand for imports. Italy's inability to access Asian markets partly explains the decline in its trade balance (Figure 8).

In addition, real effective exchange rates in Figure 10 show that Germany experienced vast improvements in competitiveness since 1998 Q1, whereas Italy lost competitiveness. Germany's improvements in cost competitiveness are primarily due to the fact that between 1997 and 2006 real disposable incomes were virtually unchanged (Burda 2007). German labour markets arguably became much more flexible as a result of the 'Hartz' reforms, which allowed the economy to absorb shocks without major losses in employment (Burda 2007). Germany's economic policies since 1997 demonstrate considerable sacrifices whilst other EMU members enjoyed protracted periods of growth and prosperity. Although this reflects foresight by German policymakers, it must be emphasised that these reforms were made possible by deviating from the SGP criteria. This leeway allowed Germany to engage in fiscal stimulus and enact a series of reforms which helped develop a robust economy and enabled a strong recovery from the global financial crisis.

Italy's poor export growth is characterised by a highly price-elastic product specialisation, losing a large part of its market share to price-competitive emerging economies (EC 2012b). Italy's current situation is reminiscent of Germany in the first half of the 2000s: Italy would benefit from structural reforms to improve productivity and price-competitiveness, as Germany did (Burda 2007). However, although such structural reforms have medium to long-term benefits, they have short-term costs; structural efforts to improve competitiveness must be preceded by efforts to improve growth.

\section{Policy options}

A number of arguments have been made in favour of continued fiscal consolidation for countries suffering Italy's symptoms (van Riet et al. 2010; Reinhart \& Rogoff 2010; Merkel 2013; Rehn 2013). Fiscal consolidation may be compatible with GDP growth, if uncertainty over sustainability of public finances depresses consumption and investment and hence growth (Giavazzi \& Pagano 1990; Afonso 2006; van Riet et al. 2010; Giudice, Turrini \& in 't Veld 2003). Yet there is little evidence of this being the case in Italy, whose debt is only a medium to long-run concern (EC 2012c). Moreover, with unemployment at almost double the March 2007 rate, domestic uncertainty is unlikely to be centred on government debt.

Another argument in favour of fiscal consolidation is that failure to reduce debt will lead to credibility losses and higher borrowing costs. This can be self-fulfilling, if higher borrowing costs lead to uncertainty over the sustainability of government finances (van Riet et al. 2010). In response, financial markets add a default risk premium on Italian sovereign bonds, which can raise the debt ratio (Figure 9). However, Paul De Grauwe and Yuemei Ji (2012) found compelling evidence that bond spreads are not correlated with the debt ratio in the Euro-zone post-2008. Instead, they found that Euro-zone bond spreads increase as the result of 'panicdriven collective behaviour' rather than poor macroeconomic fundamentals. Their findings highlight the need for a fiscal union, or at least a banking union, rather than improving any 
country's fundamentals - with the exception of Greece. The ECB 'Outright Monetary Transactions' (OMT) policy, for all its effectiveness, does not provide a long-term solution.

Although the Italian spread increased considerably towards the end of 2011 (Figure 9), there is little evidence to suggest that this reflects unsustainable macroeconomic fundamentals. The relationship between Italy's debt ratio and borrowing costs is complex; factors such as fear of contagion and political instability must be taken into account. As illustrated in Figure 9, Italian spreads increased sharply after May 2011, and peaked in November 2011 as the Italian government credit rating was downgraded (Milne 2011), spreading fears of a self-fulfilling liquidity crisis. Rates then declined as Mario Monti became Italian Prime Minister; whilst this decline might be attributed to Monti's commitment to fiscal consolidation, it is more likely that financial markets responded to the newfound political stability (Krugman 2013). Shortly after the political deadlock of spring 2013, general elections led to a further downgrade of Italy's credit rating (Moody's 2013; Landini 2013) - although macroeconomic fundamentals such as slow growth and rising unemployment were also contributing factors. Increasing Italian bond yields resulted in upward pressure on private borrowing costs, and constrained private sector investment; hence, weighing heavily on Italy's future growth potential. Arguably, the only thing that staved off a liquidity crisis before accession of the next Prime Minister, Enrico Letta, is the ECB's OMT policy (Buti \& Carnot 2013; De Grauwe \& Ji 2013). Letta had made no commitments to austerity when he took office (Mackenzie 2013); but long-term interest rates continued to decline.

\section{Figure 9}

\section{0-year government bond yields}

Source: Data from the European Commission, Eurostat (2014)

As bond yields continue towards their pre-crisis level, it becomes apparent that they - and consequently the debt ratio - respond less to austerity, and more to political and regional stability. Italian political debates prior to the spring 2013 elections were centred on the Eurozone crisis and the prospect of fiscal cuts, which highlights an important relationship: fiscal consolidation polarises opinions and leads to political instability. In turn, political instability leads to a higher debt ratio and potential speculative attacks. Italy would benefit from reducing its debt ratio but, given the current political and economic climate, severe fiscal cuts are highly unlikely to achieve this.

If fiscal consolidation is unlikely to reduce Italy's debt ratio in the short term, an alternative approach is for the Italian government to spend more and to raise taxes by the same amount. This balanced budget approach is a compromise between radical Keynesian action and austerity currently required in Italy by the SGP. There is considerable evidence that a balanced budget fiscal injection could help Italy recover from recession through the multiplier effect (Blanchard \& Leigh 2013; DeLong \& Summers 2012; Griffith-Jones \& Jolly 2013; Hatzinikolaou 2013). As argued by some (Blanchard, Amighini \& Giavazzi 2010, p. 54), only after economic activity has 
recovered should Italy attempt to reduce its long-term debt. By restoring growth, the Italian government will have more space for the implementation of much-needed structural reforms that will help reduce the debt-to-GDP ratio in the medium term. The ECB's recent considerations of engaging in quantitative easing is supporting the existing downward trend of the 10-year Italian bond yield, as it seems capable of preventing the emergence of deflation in the Italian economy. This will allow further leeway for Italy to engage in a balanced budget fiscal stimulus.

The effectiveness of fiscal policy will be determined by the size of the fiscal multiplier. An increasing number of studies indicate that multipliers are higher during recessions (Corsetti et al. 2010; Auerbach \& Gorodnichenko 2011; Blanchard \& Leigh 2013); thus, if the Italian government follows a balanced budget policy, the effect will be equivalent to a fiscal stimulus. Furthermore, a large multiplier implies that fiscal consolidation is likely to be ineffective or indeed dangerous. A balanced budget in Italy is therefore likely to stimulate growth - and reduce the debt ratio as a result; whereas fiscal consolidation risks pushing Italy into a deep recession. Therefore the EC's current emphasis on fiscal consolidation (EC 2006; EC 2011; EC 2012c) might cause a deterioration in Italy's debt ratio by further depressing growth, and also risks causing structural unemployment and permanent long-term loss in potential output growth (DeLong \& Summers 2012). As Italian unemployment increases (Figure 4), a balanced-budget fiscal stimulus may be the only way to reduce the debt-to-GDP ratio. To that extent, the SGP considerably restricts Italy's ability to scale down its debt ratio, prolongs instability, and endangers the future of the Euro-zone.

The response to the sovereign debt crisis aggravated asymmetries in the Euro-zone. The gap between the German growth-rate, and that of Italy and of the Euro-zone in general (Figure 5), has widened considerably since 2008. Whereas Italian borrowing costs have risen, German rates have decreased - reflecting the low risk premium on German bonds, and indicating capital transfers from Italy to Germany. Having stabilised its debt, Germany can now afford to run a deficit within the SGP threshold, and use part of the deficit for Euro-zone fiscal transfers (De Grauwe \& Ji 2013). Whilst this is likely to be effective, political realities remain major obstacles to solving the crisis. Yet, growing asymmetries of the Euro-zone require a system of fiscal transfers, or a system of debt mutualisation - designed for members suffering Italy's symptoms. At the very least, a banking union is necessary to prevent a repeat of the Euro-zone crisis (Lane 2012, p. 63). If the Euro-zone fails to act decisively, this is likely to lead to fewer options and greater political sacrifices in the future.

\title{
Figure 10
}

\author{
Real effective exchange rates, Index 2005Q1=100
}

Source: Data from the European Commission, Eurostat (2014) 


\section{Conclusion}

The SGP is a mechanism for maintaining fiscal prudence, which allows the ECB to focus on maintaining price stability in EMU. In that respect, the SGP could bring the benefits of fiscal union without the associated externalities. Evidence reported in this paper shows that the EMU debt crisis is widening the asymmetries between Italy and Germany, which are likely to be part of a broader pattern between the centre and periphery of the EU. Different structural compositions in different countries (e.g. being prone to different types of shocks), means that a one-size-fits-all fiscal rule might be harmful in some countries.

This paper focuses on Italy and Germany: especially the slow or non-existent recovery in Italy since the global 2008 crisis. There is no evidence in this paper to suggest Italy is unique - hence if the SGP has been harmful to Italy, it is likely to be causing problems in other peripheral Eurozone countries. There is widespread concern among economists that the SGP is preventing recovery in Europe. The SGP produced the opposite effects to what it was intended to achieve: it restricted governments' ability to use fiscal policy, without providing the benefits of a fiscal union. Adherence to the SGP is self-defeating for Italy, which (like Germany in the mid-2000s) needs to stimulate growth before engaging in fiscal consolidation. The effects of a future shock on the Italian economy will be severe if the current institutional framework remains in place. If Italy were allowed to follow Germany's example (i.e. to break the SGP rules, in order to adopt appropriate economic policies), then a faster recovery would be expected.

To protect EMU against future crises, and deal with current and future asymmetries, evidence in this paper suggests the EU should make radical changes to the SGP - or abandon it in, favour of closer fiscal integration. 


\section{References}

Afonso, A. (2006), 'Expansionary fiscal consolidations in Europe: New evidence', European Central Bank (ECB), Working Paper no. 675. [Online]. Available at:

http://www.ecb.europa.eu/pub/pdf/scpwps/ecbwp675.pdf [Accessed 17 June 2014].

Annual Macro-economic Database (AMECO), 2014, Directorate General for Economic and Financial Affairs. [Online]. Available at:

ec.Europa.eu/economy finance/ameco/user/serie/SelectSerie.cfm [Accessed 20 June 201].

Auerbach, A. J. and Gorodnichenko, Y. (2011), 'Fiscal multipliers in recession and expansion',

National Bureau of Economic Research (NBER), Working Paper no. 17447. [Online]. Available at: http://www.nber.org/papers/w17447 [Accessed 12 June 2014].

Blanchard, J. O., Amighini, A. and Giavazzi, F. (2010), Macroeconomics: a European perspective. Pearson: Harlow.

Blanchard, J. O. and Leigh, D. (2013), 'Forecast errors and fiscal multipliers'. International Monetary Fund (IMF), Working Paper no. 3/1. [Online]. Available at: www.imf.org/external/pubs/ft/wp/2013/wp1301.pdf [Accessed 15 June 2014].

Burda, M. (2007), 'German recovery: it's the supply side', VoxEU.org. [Online]. Available at: www.voxeu.org/article/german-recovery-it-s-supply-side [Accessed 15 June 2014].

Buti, M. and Carnot, N. (2014), 'Fiscal policy in Europe: Searching for the right balance', VoxEU.org. [Online]. Available at: www.voxeu.org/article/fiscal-policyEurope-searching-right-balance [Accessed 15 June 2014].

Cerra, V., Panizza, U. and Saxena, S. C. (2013), 'International evidence on recovery from recessions', Contemporary Economic Policy, Vol. 31(2), pp. 424-39.

Corsetti, G. (2012), 'Has austerity gone too far?', VoxEU.org. [Online]. Available at: 
www.voxeu.org/article/has-austerity-gone-too-far-new-vox-debate [Accessed 15 June 2014].

Corsetti, G., Kuester, K., Meier, A. and. Müller, G. J. (2010), 'Debt consolidation and fiscal stabilization of deep recessions', American Economic Review, Vol. 100(2), pp. 41-45.

Collignon, S. (2004). 'The end of the Stability and Growth Pact?', International Economics and

Economic Policy, Vol. 1(1), pp. 15-19.

DeLong, B. J. and Summers, L. H. (2012), 'Fiscal policy in a depressed economy', Brookings Panel on Economic Activity, Vol. 44(1), pp. 233-97.

De Grauwe, P. (2012), Economics of Monetary Union. $9^{\text {th }}$ ed. Oxford: Oxford University Press.

De Grauwe, P. and Ji, Y. (2012), 'Self-fulfilling crises in the Eurozone: an empirical test'. Centre for European Policy Studies (CEPS), Working Paper no. 367. [Online]. Available at: www.ceps.eu/book/self-fulfilling-crises-Eurozone-empirical-test [Accessed 20 June 2014).

De Grauwe, P. and Ji, Y. (2013) ‘Panic-driven austerity in the Eurozone and its implications'.

VoxEU.org. [Online]. Available at:. www.voxeu.org/article/panic-driven-austerityEurozone-and-its-implications [Accessed 15 June 2014].

Eijffinger, S. C.W. and De Haan, J. (2008), European monetary and fiscal policy. Oxford: Oxford University Press.

Eurostat, Statistics, European Commission, (2013). [Online]. Available at: epp.Eurostat.ec.Europa.eu/portal/page/portal/statistics/search database [Accessed 20 June 2014].

European Commission, (2006), 'The EU economy: 2006 review'. European Economy. [Online]. Available at: 
ec.Europa.eu/economy finance/publications/publication425 en.pdf [Accessed 17 June 2014].

European Commission, (2012a), 'Macroeconomic Imbalances - Italy'. European Economy Occasional Paper no. 107. [Online]. Available at:

ec.Europa.eu/economy_finance/publications/occasional_paper/2012/pdf/ocp107_en. pdf [Accessed 17 June 2014].

European Commission, (2012b), 'Tax reforms in EU Member States 2012 - Tax policy challenges for economic growth and fiscal sustainability'. European Economy. [Online]. Available at:

ec.Europa.eu/economy_finance/publications/European_economy/2012/pdf/ee-20126_en.pdf [Accessed 17 June 2014].

European Commission, (2012c), 'Fiscal sustainability report 2012'. European Economy. [Online]. Available at:

ec.Europa.eu/economy finance/publications/European_economy/2012/pdf/ee-20128 _en.pdf [Accessed 17 June 2014].

European Commission. (Various years), ‘European economic forecast'. [Online]. Available at:

ec.Europa.eu/economy_finance/publications/European_economy/forecasts/index_en. $\underline{\text { htm }}$

[Accessed 17 June 2014].

European Union, (1997), 'Treaty on the Functioning of the European Union'. Eur-Lex, 1997. [Online]. Available at: http://eur-lex.europa.eu/en/treaties/new-2-47.htm [Accessed 17 June 2014].

Giavazzi, F. and Pagano, M. (1990), 'Can severe fiscal contractions be expansionary? Tales of two small European countries'. In O. J. Blanchard and Fischer, S. (eds), Macroeconomics Annual, Vol. 5, pp. 75-122. Cambridge, Massachusetts: MIT Press.

Giudice, G., Turrini, A. and in 't Veld, J. (2003), 'Can fiscal consolidations be expansionary in the EU? Ex-post evidence and ex-ante analysis'. European Economy, Economic Paper no. 195. [Online]. Available at: http://ec.europa.eu/economy finance/publications/publication_summary6930 en.htm [Accessed 14 June 2014]. 
Griffith-Jones, S. and Jolly, R. (2013), 'Be outraged by austerity'. Challenge Vol. 56(1), pp. 40-60.

Hatzinikolaou, D. (2013), 'A simple approach to testing the potency of government purchases to stimulate aggregate demand', Journal of Reviews on Global Economics, Vol. 2, pp. 117-22.

Landini, F. (2013), 'Italy's debt cost at 2013 high on downgrade, politics', Reuters, 13 March. [Online]. Available at: uk.reuters.com/article/2013/03/13/uk-italy-debtidUKBRE92C00L20130313 [Accessed 20 June 2014].

Lane, P. R., (2012), 'The European sovereign debt crisis', Journal of Economic Perspectives, Vol. 26(3), pp. 49-67.

Krugman, P. (2013), 'Austerity, Italian style', The New York Times, 25 February, p. A17.

Mackenzie, J. (2013), 'Italy's Letta faces early squeeze over anti-austerity drive', Reuters,

1 March. [Online]. Available at: http://uk.reuters.com/article/2013/05/01/us-italypolitics-idUSBRE9400GW20130501 [Accessed 16 June 2014].

Merkel, A. (2013), 'Addressing global and European challenges', World

Economic Forum, Annual Meeting, Davos, 24 January 24. [Online]. Available at:

http://www.weforum.org/videos/addressing-global-and-european-challenges [Accessed 20 June 2014].

Milne, R. (2011), 'S\&P downgrades Italy's credit rating', The Financial Times, 20 September. [Online]. Available at: www.ft.com/cms/s/0/f48542f0-e346-11e0-8f4700144feabdc0.html\#axzz2Naj76NB4 [Accessed 20 June 2014].

Moody's, (2013), 'Rating Action: Moody's downgrades Italy's government bond rating to Baa2 from A3, maintains negative outlook', Moody's Investors Service, 13 July. [Online]. Available at: www.moodys.com/research/Moodys-downgrades-Italysgovernment-bond-rating-to-Baa2-from-A3--PR_250567 [Accessed 17 June 2014]. 
Organisation for Economic Co-operation and Development (OECD), (2011), ‘Restoring Public

Finances'. [Online]. Available at: www.oecd.org/gov/budgeting/47558957.pdf [Accessed 20 June 2014].

Rehn, O. (2013), 'Recovery from the crisis - Coherent policies for growth and jobs', ILO European Regional Meeting. European Commission. Speech, Oslo, 9 April. [Online]. Available at: http://europa.eu/rapid/press-release_SPEECH-13-294_en.htm? locale $=$ en [Accessed 20 June 2014].

Reinhart, C. M. and Rogoff, K. (2010), 'Growth in a time of debt', American Economic Review, Vol. 100(2), pp. 573-78.

van Riet, A. ed., (2010), 'Euro area fiscal policies and the crisis'. ECB Occasional Paper no. 109. [Online]. Available at: www.ecb.int/pub/pdf/scpops/ecbocp109.pdf [Accessed 20 June 2014].

World Bank, (2013), 'World Development Indicators', 1 July. [Online]. Available at: data.worldbank.org/data-catalog/GDP-ranking-table [Accessed 20 June 2014]. 